DOI 10.37882/2223-2982.2021.12.28

\title{
ТОПОНИМИКА ЧЕМАЛЬСКОГО РАЙОНА РЕСПУБЛИКИ АЛТАЙ (СТРУКТУРНО-СЕМАНТИЧЕСКАЯ И СЛОВООБРАЗОВАТЕЛЬНАЯ ХАРАКТЕРИСТИКА)
}

\section{TOPONYMY OF THE CHEMALSKY \\ DISTRICT ALTAI REPUBLIC \\ (STRUCTURAL-SEMANTIC AND \\ WORD-FORMATION CHARACTERISTICS)}

B. Sanalova

Summary: Geographical names of any territory are of interest as historical and geographical material and as a linguistic source. This article is devoted to the analysis of toponyms of the Chemalsky district of the Altai Republic at the morphological and semantic levels. On the basis of extensive material, the lexical and semantic classification of the studied toponyms is given and their structural and word-formation features are considered.

Keywords: toponymy, toponym, geographical name, structure, semantics, affixes.

Д

анная статья является попыткой дать морфологический и семантический анализ географических названий Чемальского района Республики Алтай.

Материалом исследования послужили полевые данные, собранные сотрудниками научной группы алтайского языка Научно-исследовательского института алтаистики им. С.С. Суразакова во время экспедиции по населенным пунктам Чемальского района в первом полугодии 2020 г.

Географические названия любой территории содержат в себе ценные сведения и обладают большой информативностью. Они представляют интерес и как историко-географический материал, и как лингвистический источник. По словам Э.М. Мурзаева, «... комплексный топонимический анализ всегда многофункционален. Он должен учитывать природные особенности настоящего и прошлого ареала народов, их историческое развитие, языковую специфику, материальную и духовную культуру. Все это получает отражение в топонимических системах» [5, с. 3-4]. Действительно, топонимы любой территории при всем их разнообразии оказываются тесно связанными друг с другом. Это объясняется тем, что географические названия на каждой исторически или географически выделяемой территории образуют определенную систему. Эта система обладает не только единой территориальной общностью, но и общностью
Саналова Байару Борисовна К.филол.н., с.н.С., НИИ алтаистики им. С.С. Суразакова, Горно-Алтайск sbayaru@mail.ru

Аннотация: Географические названия любой территории представляют интерес как историко-географический материал и как лингвистический источник. Данная статья посвящена анализу топонимов Чемальского района Республики Алтай на морфологическом и семантическом уровнях. На основе обширного материала дается лексико-семантическая классификация исследуемых топонимов и рассматриваются их структурно-словообразовательные особенности.

Ключевые слова: топонимика, топоним, географическое название, структура, семантика, аффикс.

языковой.

Так Ю.А. Карпенко отмечает, что «... эта система, несомненно, существует, хотя бы потому, что каждая территория имеет много топонимических названий, и они должны быть как-то упорядочены, как-то организованы и согласованы между собой, чтобы иметь возможность выполнять свои функции» [2, с. 50].

В настоящей статье на основе обширного материала дается полная характеристика семантических и структурно-словообразовательных особенностей топонимов Чемальского района Республики Алтай.

Анализ семантических и структурно-словообразовательных особенностей является неотъемлемой частью любого топонимического исследования. Согласно 3.С. Камалетдиновой, «Наряду с ономасиологическим анализом изучение морфологического и словообразовательного аспектов является важнейшим средством лингвистической информации топонимического материала [1, с. 174].

В образовании топонимической системы любой территории важную роль играют географические термины. Они «оказываются той частью сложных, составных географических названий, которые определяют смысловое содержание топонимов [5, с. 98]. В топонимии сел Чемальского района употребляются следующие 
географические апеллятивы: айры 'развилина, развилка; рукав реки', apm 'горный перевал, горный проход', боом 'скалистый выступ, обрыв, боочы 'перевал', јарык 'щель, расщелина; теснина, ущелье', јалан, јик 'лощина', кем 'река , кобы 'лог', кӧл 'озеро', межелик 'холм, сопка', ойбок 'впадина, низина', ойык 'котловина; углубление на вершине', оро 'яма', сас 'болото', суу 'река', кырлан 'пригорок', тӧн-'холм, пригорок', бугор, возвышенность', туу 'гора', кыр 'гора', ой 'рытвина, впадина', кайа 'скала', меес 'безлесная сторона горы', айан 'поляна'. Например: Ак-Айры 'открытая развилка', Кара-Кайа 'черная скала', Кара-Боом 'чёрный бом', Ак-Ой 'открытая рытвина, впадина', Тытmу-Туу 'гора с лиственницами', Јаан-Кыр 'большая гора', Кезек-Јалан 'навозное поле', Кӧл-Айан 'озеро-поляна', Сары-Меес 'жёлтая безлесная сторона горы', Суулу-Айры 'развилка с водой', Айры-Кобы 'раздвоенный лог', Ак-Кем 'белая река', Ак-Кайа 'белая скала', Кыралу-Тӧн 'пригорок с пашней', Карагайлу-Јарык 'теснина, ущелье с соснами' и т.д.

\section{1. ^ексико-семантическая к^ассификация топонимов}

Любое географическое название исторично и несет в себе какую-то информацию. В топонимах запечатлены исторические этапы заселения территории, хозяйственная деятельность людей, географические особенности местности, разнообразие природной среды. Они отражают важнейшие особенности материальной и духовной культуры народа.

С лексико-семантической точки зрения в зависимости от того, какая лексика участвует в формировании топонимов, в топонимической системе исследуемой территории можно выделить:

1. топонимы, содержащие в составе анатомическую лексику (баш 'голова' в значении 'начало; вершина, верховье', бут 'нога' в значении 'отрог горного хребта', бел 'спина, поясница' в значении 'плоская поверхность в гребне хребта, пологая возвышенность, склон, гора, перевал, седловина, средний пояс гор, увал', оос 'рот' в значении 'начало; вход; устье', кол 'рука' в значении русло реки, речная долина'). Например: Сары-Бел 'желтая ровная плоская поверхность в гребне хребта', Ӧзӧн-Оозы 'устье протоки, реки', Ак-Баш 'белая вершина', Кӧдӧнӧйдин-Бажы 'верховье Кёдёнёй', МыйрыкБут 'кривой, изогнутый отрог горного хребта' и т.д.

2. топонимы, содержащие в своем составе в качестве определяющего или определяемого компонента слова, связанные с растительным миром: Јаш-Мӧш 'молодой кедр', Карагайлу-Кобы 'лог с соснами, Кайынду-Ойбок 'низина, впадина с березами', Кызыл-Тал 'красный тальник', Кара-Тыт 'черная лиственница', Сары-Чет 'желтая молодая лиственница', Талду-Айры 'развилка с тальником',
Бӧкӧн-Кайын 'изогнутая береза', Чыналу-Кобы 'лог с чиной клубневидной', Боронот-Кобы 'лог со смородиной', Аспакту-Кобы 'лог с осинами' и т.д.;

3. топонимы, содержащие в составе в качестве определяющего компонента слова, связанные с животным миром: Борсукту-Кобы 'лог с барсуками', Текелӱ-Кобы 'лог с горными козлами') и т.д.;

4. топонимы, содержащие в своем составе лексику, отражающую характер деятельности, быт, культуру населения: Сан 'подношение, пища, которая преподносится огню', Јайлу 'летняя стоянка', Чакы 'коновязь', Манакай 'засада', Тебелӱ-Арm 'небольшой перевал с зимним пастбищем', Туру-Кобы 'лог-стойбище', Чолобо 'кусочки жертвенного мяса, которые разбрасывают во время жертвоприношения', Кам-Тыт 'шаманская лиственница', Кам-Сӧӧк 'могила шамана', Курманду-Кобы 'лог с жертвоприношением' и т.д.;

5. топонимы, содержащие в составе лексику, отражающую исторические события и имена бывших владельцев земель (имена, фамилии, названия родов): Мегедек-Јурт 'жилище Мегедек', Арбанак-Кобы 'лог Арбанака', Матвей-Јурты 'жилище Матвея', Мундус-Коол 'русло мундусов', БыйдышКобы 'лог Быйдыш'.

\section{2. Структура и способы образования топонимов}

В работе структурный анализ топонимов проводится по двум признакам:

1. количество входящих в топоним компонентов;

2. способ словопроизводства. По количеству составляющих компонентов рассматриваются простые и сложные топонимы.

\section{1. Простые топонимы}

Простые топонимы, можно разделить на две подгруппы:

1. тождественные географическим терминам и являющиеся названиями конкретного географического объекта: Боочы ‘букв. перевал', Межелик 'сопка', Сойок 'небольшая гора', Аpm 'невысокий перевал', Ӧзӧн 'река', Јарык 'расщелина' и т.д.;

2. представляющие собой другие лексические основы: а) топонимы, выраженные именем существительным: Јодо 'голень', Энмек 'темя, макушка', Сокы 'ступа', Кайым 'пучина, водоворот', Туру 'стойбище', Казан 'котел, казан', Туткуш 'ручка, держалка; прихватка', Тежик 'дыра, отверстие' и т.д.; б) топонимы, выраженные именем прилагательным: Чичке 'узкий', Чанкыр 'голубой', Бешпек 'пухлый, полный', Атрах / Атрак 'лохматый', Шаркырак 'журчащий' и т.д.; в) топонимы, образованные от наречия: Кырдай 'близко к горе; по подножию горы, вдоль горы', Југунда / Јуугында 'близко, рядом'; г) топонимы, образованные от глаголов: 
Бедиреген 'искал; который искал', Јаппаган 'не закрыл; не закрывший', Кӱркӥре 'громыхать'.

Наиболее продуктивным в образовании простых производных топонимов является афф. -лу, указывающий на обладание, изобилие или наличие чего/кого-н.; признак: Кендирлӱ 'с коноплей’, Кӧбӧлӧктӱ 'с бабочками', Айулу 'с медведем; имеющий медведей', Балыкту 'рыбный, с рыбой', Борсукту 'с барсуками, барсучий', Талду 'с тальником', Калбалу 'с черемшой, Јодралу 'черёмуховый, с черёмухой', Јыланду 'змеиный; со змеями', Суулу 'водный, речной; с водой, с рекой', Јытту 'пахучий, с запахом, имеющий запах', Эдектӱ 'с подолом, с полой, с подножием', Амбарлу 'амбарный, с амбаром' и т.д.

Кроме того, в морфемном составе простых топонимов встречаются аффиксы с уменьшительно-ласкательным значением -ак / -ок, -аш / -еш, -(ы)чак: Некейек 'шубка' (некей 'шуба из овчины', + -ек), Кайынаш 'березка' (кайын 'березка' + -аш), Койонок 'зайчик' (койон 'заяц' + -ок), Кумучак 'песочек' (кум 'песок' + -учак). По поводу употребления уменьшительно-ласкательного аффикса в тюркских топонимах Мурзаев Э.М. пишет, что «этот аффикс информирует о малых размерах называемого географического объекта, а не апеллятива» [5, с. 88]. Например, топоним Кайынаш 'березка' (кайын 'березка' + -аш) указывает на малые размеры географического объекта, а не дерева.

Также встречаются топонимы, образованные присоединением к алтайскому слову русского словообразовательного суфф.: Актатайка (Актатай + -к +-a), Чепошка $($ Чопош + -к +-a), Талдушка (Талду + -шк + -a).

\section{2. Сложные топонимы}

Сложные топонимы делятся на однословные и топонимы-словосочетания.

\section{ОАнословные сложные топонимы}

Однословные сложные топонимы образуются путем стяжения двух основ без усечения (стяжение полных основ) или с усечением одной из них: Агалак (от ак 'открытый; голый, без растительности' + алаак 'лесная поляна (в пойме реки и на островах)', Ороктой (от орык 'тропа' с афф. облад -ту + апеллятив ой 'рытвина; яма; котловина; впадина'), Эликманар (от элик 'косуля' + манар 'огородит, будет огораживать; огораживающий'), Онос (от он 'десять' и оос 'устье'), Манјӱрек (от ман 'быстро, стремительно' и јӱрек'сердце', Тоной (от тон'мёрзлый' и ой 'низина, котловина; углубление, яма'), Барантал ( от бараан 'темный цвет' и тал 'тальник, ива').

\section{Топонимы-словосочетания}

Топонимы-словосочетания образуются путем сочета- ния двух и более компонентов.

\section{$\triangle$ вухкомпонентные сложные топонимы}

Двухкомпонентные сложные топонимы состоят из двух компонентов: определения и определяемого. Определяемое слово в составе топонимов является главным компонентом. Этот компонент всегда выражен именем существительным. В качестве определения, зависимого компонента, могут выступать имена существительные, имена прилагательные и числительные.

Сложные топонимы с определяющим компонентом именем существительным

Между компонентами сложных топонимов с определяющим компонентом именем существительным прослеживаются отношения принадлежности, свойственные сочетаниям изафетного типа (1 тип изафета, 2 тип изафета, 3 тип изафета).

Топонимы, построенные на изафетной связи первого типа, когда оба компонента не имеют никаких грамматических показателей, имеют следующую модель: сущ.Ø +сущ.Ø: Ийт-Кайа 'собачья скала', БӧдӧнӧКобы 'перепелиный лог', Кӧжӧӧ-Јалан 'поле-занавес', Кӧл-Айан 'озеро-поляна', Сарас-Кыр 'гора-колонок', Тенгери-Айры 'небесное разветвление', Ан-Тыт 'оленья лиственница' и т.д.

В топонимах, построенных на изафетной связи второго типа, первый компонент, определение, грамматически не оформлено, второй компонент, определяемое слово, имеет афф. принадл. 3 л. -и /-ы (после согласных), -зы /-зи (после гласных): Бандит-Кобызы 'бандитский лог', Куш-Уйазы 'птичье гнездо', Чичке-Боочызы 'перевал Чичке' и т.д.

В топонимах третьего типа изафетной конструкции первый компонент, определение, оформляется афф. притяж. п. -нын / -нин, второй компонент, определяемое слово, - афф. 3 л. -и /-ы (после согласных), -зы /-зи (после гласных): Кӧдӧнӧйдин-Суузы 'вода местности Кёдёнёй', Мыйтунын-Боочызы 'Мыютинский перевал', Чобрактын-Бажы 'Вершина Чобрак' и т.д.

Сложные топонимы с определяющим компонентом именем прилагательным

В состав сложных топонимов с определяющим компонентом именем прилагательным могут входить непроизводные прилагательные (как правило, качественные прил.): Мерген-Суу 'проворная река', Терен-Јик 'глубокая лощина', Туйук-Кобы 'закрытый лог', Темир-Ойык 'железное углубление', Коо-Сас 'изящное болото', Бозыр-Таш 'шероховатый камень', Айры-Кобы 'раздвоенный лог', чичке-Айан 'узкая поляна', Кара-Јӱрек 'черное сердце', 


\section{Јаман-Јол ‘плохая дорога’ и т.д.}

Производные прилагательные, входящие в состав топонимов, в большинстве случаев имеют словообразующий афф. -лу: Суулу-Айан 'поляна с водой', Тошту-Кобы 'лог со льдом', Taumy-Kam 'каменный слой' и т.д.

Кроме того, очень часто в формировании сложных топонимов участвуют так называемые слова-ориентиры - прилагательные алтыгы 'нижний', ӱстиги 'верхний', орто 'средний': Ӱстиги-Куйус 'Верхний Куйус', АлтыгыКорочы 'Нижний Корочы', Орто-Куйум 'Средний Куйум'; прилагательные, указывающие на размер, площадь географического объекта, јаан 'большой' и кичӱ, кичинек 'малый, маленький': Јаан-Ойбок 'Большой Ойбок', КичӱОйбок 'Малый Ойбок', Јаан-Балыкту 'Большая Балыкту', Кичинек-Балыкту 'Малая Балыкту' и т.д.

Сложные топонимы с определяющим компонентом именем числительным

В состав сложных топонимов, определяющий компонент которых выражен числительным, как правило, входят количественные числительные: Тогус-Каан 'девять ханов', Тогус-Ажу 'девять горных перевалов', Он-Тыт 'десять лиственниц', Сегис-Салковый 'восемь рублей, восемь целковых'.

\section{С^ожные топонимы глагольной конструкции}

В формировании сложных топонимов глагольной конструкции, как правило, участвуют глагольные формы на -ган и -ар, причем глагольный компонент находится в постпозиции по отношению к объекту: Тыт-Кескен '[место, где] лиственницу пилили', Am-Тудар '[место, где] коней ловят', Кой-Тайган '[место, где] овцу в жертву приносили; принесший в жертву овцу), Эчки-Тайган '[место, где] козу в жертву приносили, принесший в жертву козу', Бий-Туткан '[место, где] господина поймали', Јер-Кӧчкӧн '[место, где] земля сместилась', Ийт-Јелген '[место, где] собака бежала', Кам-Јаткан '[место, где] шаман жил', уйТӥшкен '[место, где] корова провалилась'.

\section{Многокомпонентные сложные топонимы}

Многокомпонентные сложные топонимы составными компонентами могут включать:
1. сложный топоним в качестве определения и апеллятив: Межей-Кобынын суузы 'вода лога МежейКобы', Ак-Айрынын арты 'небольшой перевал АкАйры', Ак-Кемнин боочызы 'Ак-Кемский перевал', Ак-Кайанын аржаны 'целебный источник Ак-Кайа', Урлу-Аспактынббоочызы 'Урлу-Аспакский перевал';

2. имя прилагательное в качестве определения и сложный топоним в качестве определяемого слова: Алтыгы Кара-Суу 'Нижний Кара-Суу', Јаан Чанкыр-Кобы 'Большой Чанкыр-Кобы', Кичинек Кара-Суу 'маленький Кара-Суу', Кичӱ Кортук-Арm 'Малый Кортук-Арт';

3. сложный двухкомпонентный топоним в качестве атрибутива и сложный двухкомпонентный топоним в качестве определяемого: Ак-Таштын КуйТажы 'Ак-Ташская пещера'.

Таким образом, структурно-словообразовательный и семантический анализ топонимов Чемальского района Республики Алтай показал, что функционируют простые и сложные названия. Среди простых выделяются простые топонимы, соответствующие географическим терминам и являющиеся названиями конкретного географического объекта, и простые топонимы, представляющие собой другие лексические основы. Сложные топонимы делятся на однословные топонимы и топонимы-словосочетания. Атрибутив в структуре сложного топонима может быть выражен именем существительным, именем прилагательным, числительным или иметь глагольную конструкцию.

Основным структурным типом сложных топонимов Шебалинского района являются определительные словосочетания, построенные на изафетной связи первого, второго и третьего типа. Для топонимов характерно однокомпонентное, двухкомпонентное и многокомпонентное образование. Наибольшую часть составляют двухкомпонентные географические названия.

В образовании географических названий выявлена роль топонимических аффиксов. Наиболее продуктивным в формировании простых производных топонимов является афф. -лу, редко - аффикс -лык. Кроме того, в образовании простых топонимов участвует афф. мн. ч. -лар и афф. с уменьшительно-ласкательным значением - ак / -ок, -аш / -еш. В двухкомпонентных топонимах наиболее распространен афф. -лу.

\section{ЛИТЕРАТУРА}

1. Камалетдинова 3.С. Тюркская ландшафтная лексика Нижнего Притомья. - Томск: Изд-во Томского университета, 2019. - 257 с.

2. Карпенко Ю.А. Принципы топонимики / Ю.А. Карпенко. - М.: Московский рабочий, 1964. - 178 с.

3. Матвеев А.К. Методы топонимических исследований. - Свердловск, 1986. - 101 с.

4. Молчанова 0.Т. Топонимический словарь Горного Алтая / Под редакцией к.ф.н. А.Т. Тыбыковой. - Горно-Алтайск: Горно-Алтайское отделение алтайского книжного издательства, 1979. - 400 с. 
5. Мурзаев Э.М. Тюркские географические названия. - Москва: Издательская фирма «Восточная литература» РАН, 1996. - 253 с. ○ Саналова Байару Борисовна (sbayaru@mail.ru).

Журнал «Современная наука: актуальные проблемы теории и практики»

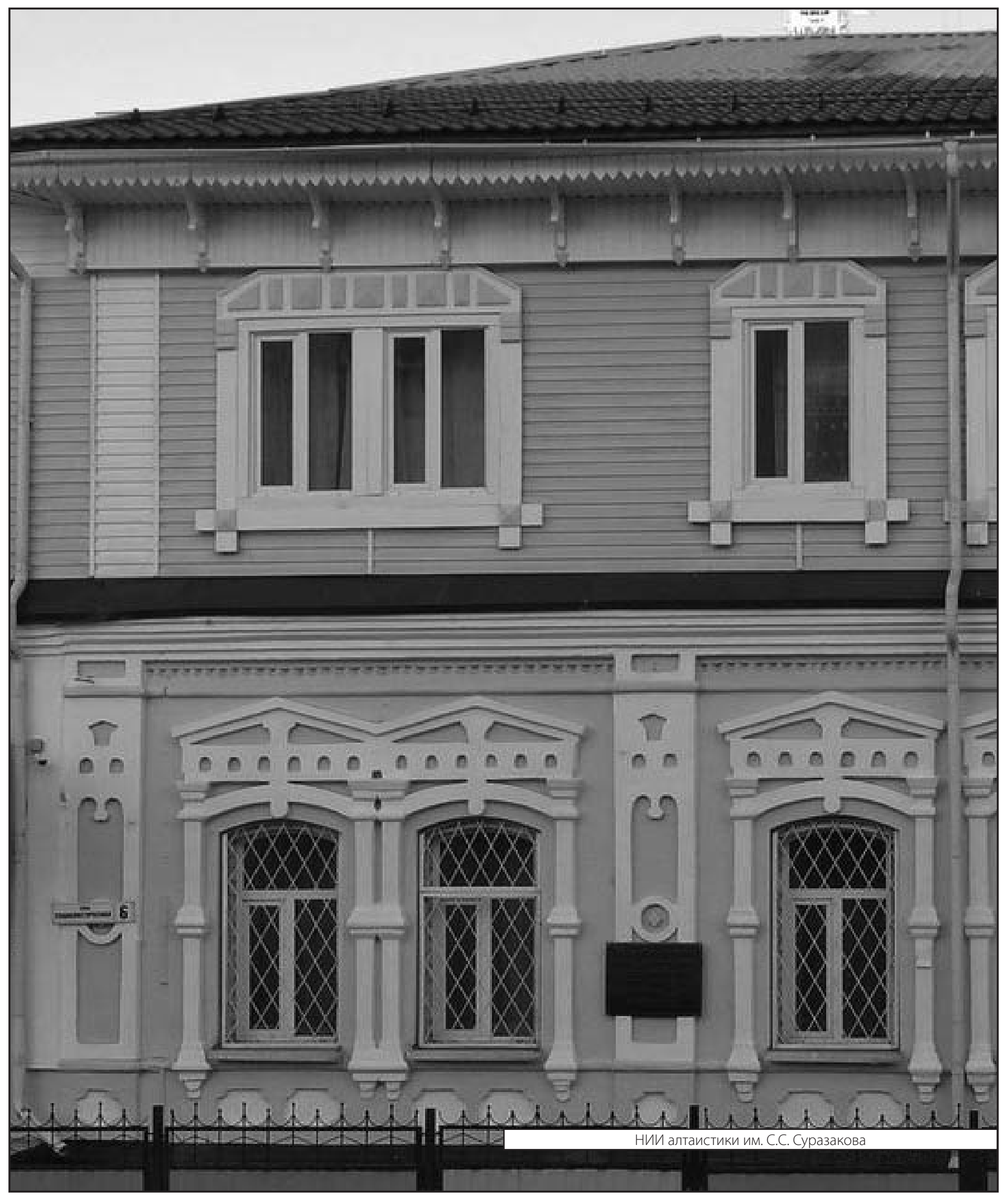

